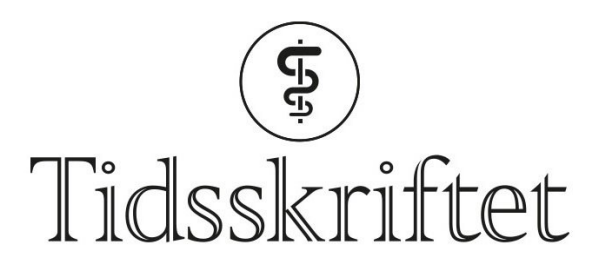

DEN NORSKE LEGEFORENING

\title{
Forbudt forskning
}

MINILEDER

\section{ARE BREAN}

Sjefredaktør

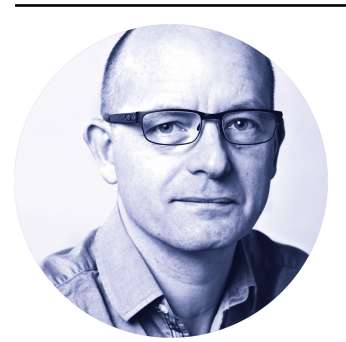

Det er lett å tenke på pressefrihet, og ikke minst mangel på sådan, som noe som først og fremst angår nyhetsmedier. Men nylig ble det kjent at kinesiske myndigheter har sperret internettilgang i Kina for 83 av forlagshuset Taylor \& Francis' vitenskapelige tidsskrifter. Tidligere har Kina blokkert tilgangen til omtrent $1 \%$ av alle artikler publisert hos Springer Nature, som blant annet utgir tidsskriftene Nature og Scientific American. Andre forlagshus har vært utsatt for det samme.

Kina er blitt verdens største produsent av vitenskapelige artikler, ifølge en rapport fra det amerikanske National Science Foundation (NSF) som kom i januar 2018. Når kinesiske myndigheter bedriver sensur av hvilken forskning som kan leses, er det all grunn til å tro at de også sensurerer hva som kan forskes på og publiseres. Det bør bekymre flere enn kinesiske forskere.

Publisert: 11. februar 2019. Tidsskr Nor Legeforen. DOI: 10.4045/tidsskr.19.03.01

(C) Tidsskrift for Den norske legeforening 2020. Lastet ned fra tidsskriftet.no 